\title{
Willingness to initiate spice-tourism in the Kolonna District Secretariat of Ratnapura district in Sri Lanka: Farmers' perspective
}

\author{
S.H.P. Malkanthi ${ }^{*}$, A.S.F. Ishana', P. Sivashankar1 and J.L.K. Weeralal ${ }^{2}$
}

\begin{abstract}
A study was conducted to assess the factors affecting the establishment of spice tourism in spice gardens in Sri Lanka, based on farmers' perception including their willingness to start agro-tourism destinations. A sample of 6ospice-growing farmers was randomly selected for the study from among those who have registered under the Department of Export Agriculture (DEA) in the Kolonna District Secretariat (DS) division in the Ratnapura district of Sri Lanka. A field survey was conducted using a pre-tested questionnaire. Data collection was conducted during from January to April 2014. Descriptive statistics and Chi Square test were used to analyze the data. Results revealed that the majority of the spicegrowing farmers were males and above 50 years old. They had education up to G.C.E. Ordinary Level $(\mathrm{O} / \mathrm{L})$, more than five members in a family, and long term experience in farming. The main reasons for farmers to start spice tourism destinations were better usage of the farm's resources, employment opportunities for the family members, support from other existing tourist location and the interest or being a hobby. Furthermore, middle-age farmers having a significant level of education, large size of farm, higher annual income of the family, high profit from farm, large family size and long term experiences had associations with willingness to start spice tourism destinations. The study concluded that there is a significant number of positive factors for farmers to establish spice tourism in the Kolonna DS division. The government of Sri Lanka could assist this endeavor by giving education and training, improving infrastructure facilities and also motivating and assisting farmers to establish spice tourism destinations in the Kolonna DS division as an extra income generating activity.
\end{abstract}

Keywords: Agro tourism, spice crops, spice gardens, spice tourism, Sri Lanka

\section{Introduction}

"Agro tourism is a commercial enterprise on a working farm, ranch, or agricultural plant conducted for the enjoyment of visitors that generates supplement income for the owner" (Mahaliyanaarachchi, 2014).In addition, agro tourism is an important option for farmers to diversify their farming operations that will bring more economic activities to rural areas. Agro tourism can be viewed as small scale, low impact, education-focused and recreational activity (Mnguni, 2010)

Agriculture has been the oldest vocation in all countries since the Neolithic revolution (Senanayakeand Wimalaratana, 2008). Agro-tourism is all about

\footnotetext{
1 Faculty of Agricultural Sciences, Sabaragamuwa University of Sri Lanka

2 Department of Export Agriculture, New Town, Ratnapura, Sri Lanka

* Corresponding author: malkanthi09@sab.ac.lk
} 
unravelling various aspects of village life including opening up farms to tourists from cities and abroad, and letting them spend some time in the lap of nature (Barbieri, 2013). Apart from telling them about the various crops and how they are sown and harvested, agro-tourism exposes tourists to authentic food, handicraft, dress, culture, music and language. Tourists get to involve in rural activities such as bullockcart rides, milking cows and goats and picking farm-fresh fruits and vegetables. These activities may vary from village to village. Introduction of agro-tourism under different themes would be of great significance and would improve the overall economic, social, cultural, and aesthetic level of the areas (Das and Rainey, 2010; Colton and Bissix (2005). Wet Zone (WZ) of Sri Lanka has been the home for the major plantation crops and spices for centuries (Punyawardena, 2007). Though agrotourism in Sri Lanka is still at its infant stage, the country has a huge potential to expand the agro-tourism sector (Malkanthi and Routry, 2012).

Sri Lanka is famous for its spices, exporting a range of products including cinnamon, pepper, cloves, nutmeg and cardamom. The Ratnapura district of the Sabaragamuwa province contributes to $10 \%$ of the total cultivation of cinnamon and $13 \%$ of pepper (DEA, 2014). Many spices such as cinnamon, pepper, cardamom, citrus, cloves, fennel, garlic and nutmeg are grown in the Kolonna District Secretariat (DS) division in the Ratnapura district, providing a significant income to the people. The cultivation and processing of spice crops are assisted by the Department of Export Agriculture. This DS division is also a famous tourism destination with sites such as the Maduwanwela Walauwwa, Panamura Ethgala, Waulpane cave, etc.

Though most of the people in the Kolonna area cultivate one or more spice crops, harvesting of spice crops is mainly done once a year.These spice farmers face difficulties in having a significant source of income during the rest of the period during a year. Furthermore, they face financial difficulties when price reductions take place in the world market. Thus, there is a need for alternative income-generating opportunities. In tourism industry, agro (spice)-tourism is a sub sector that is gradually gaining popularity at present. Tea tourism, wine tourism, spices tourism, etc. are among the many sub divisions in agro-tourism. This study focuses on initiation of spice tourism in the Kolonna area by evaluating the potential of the area and the farmers' perception on it.

\section{Conceptual Framework of the Study}

Conceptual framework (Figure 1) illustrates three important aspects of agrotourism. Left side of Figure 1 highlights agrotoursim as an important sector in tourism industry as of now. The different subsectors of agrotourism have been stated in the central part. The relationships of objectives of the study have been stated in the right side of Figure 1. 


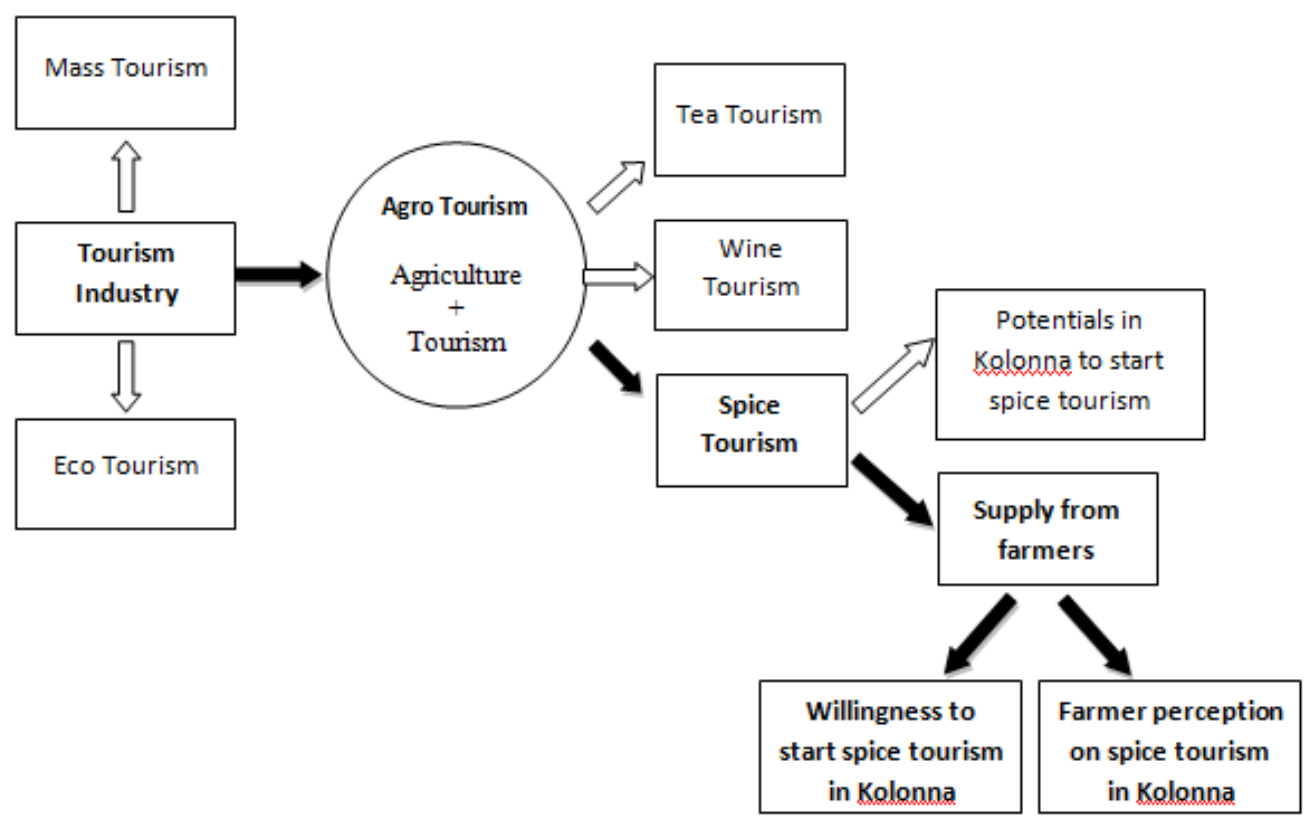

Figure 1. Conceptual framework for the study (Note: Bold fonts and bold arrows show the path of this research and normal fonts and unfilled arrows show the other links available in the system)

\section{Research Method}

\section{Study area}

The study area that was selected for the research study was the Kolonna DS division in Ratnapura district (Figure 2). The area was selected purposively due to being a suitable area to promote spice tourism within the Ratnapura district considering the extent of spice cultivation. The agro-climatic features and the soil conditions are also favourable for spice cultivation.

\section{Research design}

There were 240 farmers in the Kolonna DS division who have registered under the DEA. They were considered as the sampling frame and out of them, 60 farmers $(25 \%)$ were randomly selected for the sample of the study. Primary data including quantitative and qualitative variables were collected from the farmers during January-April 2014. Few group discussions with farmers were conducted to obtain detailed information on important aspects such as farmer attitude, opporutnities, issues and chellenges of agrotourism. Descriptive analysis was conducted to assess the demographic factors of the farmers. 


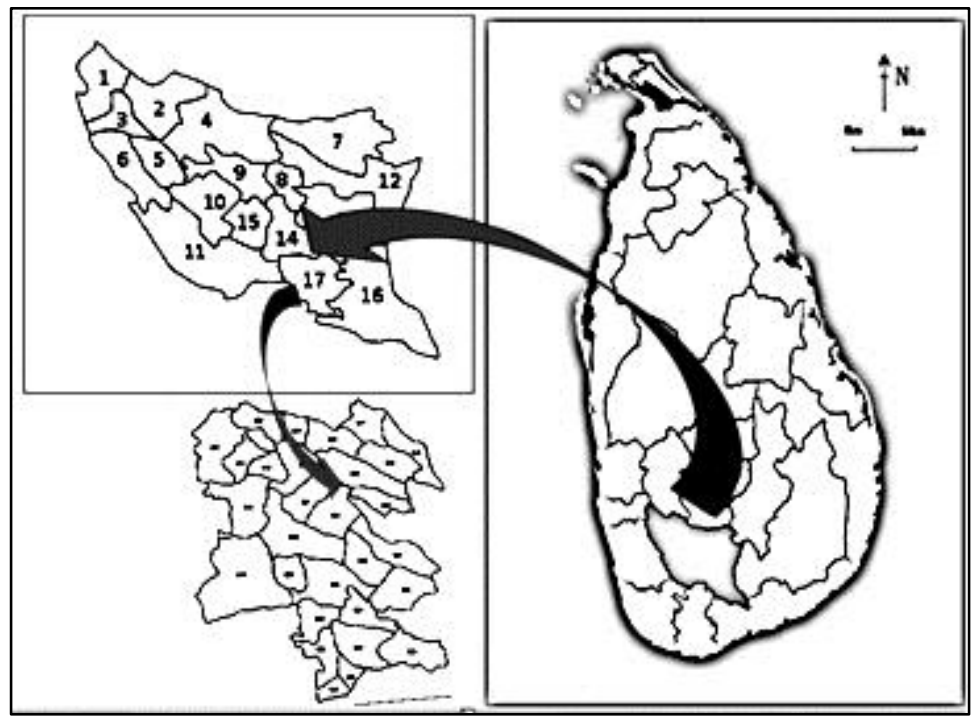

Figure 2. Sri Lanka map showing Kolonna DS division in the Ratnapura district

To investigate the reasons and limitations for initiating spice tourism, respondents were asked to mark their level of agreement by ranking the given statements using number in a Likert scale. The statement received the smallest value in ranking (from 1 to 5), was considered as the most important statement (Reason or limitation). Chi square analysis was applied to find the association between the demographic factors of farmers with their willingness to initiate spice tourism.

\section{Results and Discussion}

Results of the study are presented under four sections namely, socio-economic factors and other useful information of farmers, reasons to start and not to start spice tourism destination in the area, factor association with willingness of farmers to start spice tourism, and strengths, weaknesses, opportunities and threats (SWOT) for starting spice tourism in the Kolonna DS division.

\section{Socio-economic factors of farmers}

Socio-economic characteristics of the farmers in the area are shown in Table 1. The majority of farmers in the study sample were above 50 years old ( $80 \%$; Table 1), followed by the age groups $41-50(12 \%)$ and $31-40$ (8 \%). Most of the farmers had a considerable level of experience, interest and knowledge in farming due to long years of farming. Past experience in farming is highly useful for successful cultivations in future, too. 
Table 1. Socio-economic factors of the farmers in the study site

\begin{tabular}{|c|c|c|}
\hline Socio-economic characteristics & Frequency & $\begin{array}{c}\text { Percentag } \\
\mathrm{e}\end{array}$ \\
\hline \multicolumn{3}{|l|}{ Age } \\
\hline $31-40$ & 5 & 8 \\
\hline $41-50$ & 7 & 12 \\
\hline $51-60$ & 24 & 40 \\
\hline$>60$ & 24 & 40 \\
\hline \multicolumn{3}{|l|}{ Gender } \\
\hline Male & 51 & 85 \\
\hline Female & 9 & 15 \\
\hline \multicolumn{3}{|l|}{ Education level } \\
\hline No formal education & 2 & 03 \\
\hline Up to grade 5 & 13 & 22 \\
\hline From grade 6 to 9 & 13 & 22 \\
\hline Up to G.C.E O/L & 31 & 51 \\
\hline Up to G.C.E A/L & 1 & 2 \\
\hline \multicolumn{3}{|l|}{ Family size } \\
\hline Below 3 & 4 & 7 \\
\hline 3 members & 0 & 0 \\
\hline 4 members & 7 & 11 \\
\hline 5 members & 9 & 15 \\
\hline above 5 & 40 & 67 \\
\hline \multicolumn{3}{|l|}{ Land ownership } \\
\hline Own & 53 & 8 \\
\hline License & 7 & 12 \\
\hline \multicolumn{3}{|l|}{ Size of the farm land } \\
\hline Below or similar to $1 \mathrm{ac}$ & 14 & 23 \\
\hline Between 1.1 to 4 ac & 40 & 67 \\
\hline Between 5 to $10 a c$ & 5 & 8 \\
\hline Above 10 ac & 1 & 2 \\
\hline \multicolumn{3}{|l|}{ Experience in farming } \\
\hline Between 2 to 5 years & 1 & 2 \\
\hline Between 5 to 9 years & 3 & 5 \\
\hline Between 10 to 15 years & 11 & 18 \\
\hline Above 15 years & 45 & 75 \\
\hline \multicolumn{3}{|l|}{ Annual Income (LKR) } \\
\hline Between 10,001- 20,000 & 3 & 5 \\
\hline Between 20,001-30,000 & 2 & 3 \\
\hline Between 30,001-50,000 & 3 & 5 \\
\hline More than 50,001 & 52 & 87 \\
\hline \multicolumn{3}{|l|}{ Profitability of farm } \\
\hline a profitable business & 39 & 65 \\
\hline makes some profit & 20 & 33 \\
\hline operates at a loss & 1 & 2 \\
\hline
\end{tabular}


Participation of males in farming was higher than females. Sri Lanka is still a male dominant society. However, females help males in farming and allied activities to a greater extent. About 51 \% of farmers had education up to G.C.E O/L and overall, $97 \%$ of farmers had primary school education. Therefore, the study sample had a significant level of education to conduct good farming practices as well as tourism operations. Furthermore, it is significant that a higher number $(67 \%)$ of farm families have more than 5 members in their families. This is a significant opportunity for farming as well as for tourism especially in securing labour for those activities. The land ownership was high however, the majority of farmers $(67 \%)$ have farm lands between 1.1 ( $0.455 \mathrm{ha}$ ) to 4 acres (1.62 ha). A small percentage of farmers in the sample had land sizes above 10 acres (4.04 ha) indicating the small and medium scale farming within the study sample. Moreover, the majority of farmers were (87\%) earned above Rs. 50,000 per annum indicating that spice cultivating farmers earn a significant level of income annually whereas $65 \%$ of the study sample felt that it is a profitable business.

\section{Other useful information of the area}

The distance to spice gardens and type of spice crops cultivated by the farmers are considered as other important information of the stud area. Information related to these two aspects is presented in the Table 2.

Table 2. Other useful information of the area

\begin{tabular}{rcc}
\hline Other useful information & $\begin{array}{c}\text { Frequenc } \\
\text { y }\end{array}$ & Percentage \\
\hline Distance from Kolonna town & & \\
Less than 5km & 22 & 37 \\
Between 5 to 9km & 35 & 58 \\
Between 10 to 19km & 3 & 5 \\
Cinnamon & 36 & 60 \\
Pepper & 45 & 75 \\
Type of spice crops cultivated by farmers & 5 & 8 \\
Tea with Cinnamon or Pepper & 5 & 35 \\
Cinnamon and Pepper & 21 & 33 \\
Pepper and Banana & 20 & \\
\hline
\end{tabular}

About $37 \%$ of farmers had their farm lands close to Kolonna town (less than $5 \mathrm{~km}$ distance) and $58 \%$ had their lands 5-9 km away from the city indicating that most of the spice gardens are close to the town. This provides a good opportunity for agrotourism. Results presented in Table 2 also shows the crop combinations used by farmers in cultivating spice crops in the area thus indicating another opportunity for initiation of spice tourism in the area. 


\section{Reasons to start spice tourism in the Kolonna DS division}

The first reason for stating spice tourism in the area (Table 3) was "Kolonna is a major spices producing area in Sri Lanka" followed by (2) "Generating employment for family members", (3) "As interests or hobbies" and (4) "Agro-tourism is a high profit-generating business" respectively. Moreover, fifth and sixth reasons were "There is a high potential to establish spices gardens" and "Other tourists places are already exist to support agro-tourism". Other important reasons are "Kolonna is already established as one of the top tourist destination", "Better use of the farm's resources" and "There are good communication and transport facilities". Therefore, it is clear that there are many opportunities to initiate spice tourism in the study area.

Table 3. Reasons to start spice tourism by farmers in Kolonna

\begin{tabular}{lccc}
\hline Reasons & Mean & Mode & SE* \\
\hline $\begin{array}{l}\text { Other tourist places are already exist to support agro } \\
\text { tourism }\end{array}$ & 4.85 & 5 & 2.84 \\
$\begin{array}{l}\text { There are good communication and transport facilities } \\
\text { Kolonna is major spices producing area in Sri Lanka and }\end{array}$ & 8.36 & 8 & 1.11 \\
$\quad$ there is high potential to establish spices gardens & 3.34 & 1 & 2.49 \\
$\begin{array}{l}\text { Kolonna is already established as one of the top tourist } \\
\quad \text { destination }\end{array}$ & 5.49 & 6 & 1.96 \\
$\begin{array}{l}\text { For the better usage of the farm's resources } \\
\text { For employment for family members }\end{array}$ & 6.19 & 7 & 1.88 \\
For interests or hobbies & 3.23 & 2 & 1.77 \\
\hline
\end{tabular}

*SE - standard error

\section{Limitations to start spice tourism by farmers in the Kolonna DS division}

The first limitation to start spice tourism in the Kolonna DS division is "Ignorance of the farmers" (Table 4), suggesting that farmers have enough knowledge regarding such type of activities. "Lack of capital to develop basic infrastructure for the spice tourism", "Fear of destruction of the rural culture of society", "Lack of support from the government", "Difficult to ensure hygiene and basic requirements considering urban visitors" and "It destroys the beauty of nature" are the other main limitations faced by the farmers. Attention should be paid to overcome these constraints.

Factors association with willingness of farmers to start spice tourism in the Kolonna DS division

Nine important variables on willingness to start agro tourism operations were identified by referring to literature (Table 5). All the variables listed in Table 5 had a significant association ( $p<0.05)$ with willingness to start spice tourism. Thus, there is a clear trend to initiate spice tourism in the area. 
Table 4. Limitations to start spice tourism

\begin{tabular}{|c|c|c|c|}
\hline Limitation & Mean & Mode & SE \\
\hline Lack of knowledge & 2.231 & 2 & 1.363 \\
\hline Lack of support from the government & 5.231 & 5 & 1.964 \\
\hline $\begin{array}{l}\text { Lack of capital to develop basic infrastructure for the } \\
\text { spice tourism }\end{array}$ & 2.385 & 3 & 1.387 \\
\hline $\begin{array}{l}\text { Ignorance of the farmers regarding to the such type of } \\
\text { activities }\end{array}$ & 3.846 & 1 & 1.573 \\
\hline $\begin{array}{l}\text { Difficult to ensure hygiene and basic requirements } \\
\text { considering urban visitors }\end{array}$ & 4.462 & 6 & 1.506 \\
\hline It destroys the rural culture of society & 4.231 & 4 & 2.006 \\
\hline It destroys the beauty of nature & 5.692 & 7 & 1.797 \\
\hline
\end{tabular}

Table 5.Willingness of farmers to start spice tourism

\begin{tabular}{lccl}
\hline Variable & Chi square value & Degree of freedom & P value \\
\hline Size of farm land & 11.67 & 1 & 0.001 \\
Distance & 10.13 & 1 & 0.001 \\
Income & 8.58 & 1 & 0.003 \\
Profitability & 9.20 & 1 & 0.002 \\
Age & 5.00 & 1 & 0.025 \\
Gender & 8.37 & 1 & 0.004 \\
Size of family & 5.86 & 1 & 0.015 \\
Education & 13.83 & 1 & 0.000 \\
Experience of & 10.32 & 1 & 0.001 \\
farming & & & \\
\hline
\end{tabular}

Strength, weaknesses, opportunities and threats (SWOT) in starting spice tourism in the Kolonna DS division

Strength, weaknesses, opportunities and threats (SWOT) in starting spice tourism in the area were studied in detail. The findings are presented in the Table 6clealry indicating that there are a significant number of strengths and opportunities in the study area to initiate spice tourism. Although few weaknesses and threats were identified, they can easily be managed through the intervention of local and national government institutions.

Kolonna is a major spice-producing area in Sri Lanka, generating employment for family members and agro-tourism would be a high profit-generating business. There are several reasons behind farmers' decision on initiating agro (spice)-tourism that have add negative pressure on initiating and developing spice tourism in the area successfully. Furthermore, lack of knowledge was the main limitation to initiate such an activity. Hence, the study shows that the spice-growing farmers need specific assistance and resources form respective local and government institutions to 
develop spice tourism successfully. Despite these limitations, there is a willingness to start spice tourism, which needs to be exploited.

Table 6. SWOT analysis for starting spice tourism in the Kolonna DS division

\begin{tabular}{|c|c|}
\hline Strengths & Weaknesses \\
\hline $\begin{array}{l}\text { Diversity in farming as well as spice } \\
\text { cultivations. } \\
\text { Clear ownership of the spice land/s. } \\
\text { Vast knowledge and long term } \\
\text { experience in spice cultivation and } \\
\text { processing. } \\
\text { Larger family sizes of the farmers. }\end{array}$ & $\begin{array}{l}\text { Lack of own capital. } \\
\text { Lack of knowledge in English language. } \\
\text { Lack of knowledge in entrepreneurial skills, } \\
\text { business management. } \\
\text { Lack of technology and know-how. }\end{array}$ \\
\hline Opportunities & Threats \\
\hline $\begin{array}{l}\text { Availability of other tourist attractive } \\
\text { places in the area. } \\
\text { Getting very good support of DEA for } \\
\text { spice cultivation. } \\
\text { High demand from urban visitors. } \\
\text { Presence of knowledgeable and } \\
\text { energetic farming community. } \\
\text { Availability of tourists in the area all } \\
\text { around the year. }\end{array}$ & $\begin{array}{l}\text { Insufficient extension services. } \\
\text { Insufficient support and poor infrastructure } \\
\text { facilities. } \\
\text { Lack of promotion/ publicity and marketing } \\
\text { for agro tourism. } \\
\text { Unavailability of rules, regulations and } \\
\text { policies to improve agro tourism. } \\
\text { Lack of government support. } \\
\text { Competition from other traditional holiday } \\
\text { destinations. } \\
\text { Environmental pollution due to gradual } \\
\text { damage to the environment. }\end{array}$ \\
\hline
\end{tabular}

\section{Conclusion}

The study revealed that the socio-economic conditions of the farmers in the Kolonna DS division in Ratnapura district of Sri Lanka favours initiation of spice tourism in the area. Majority of farmers are educated, with more than 10 years of farming experiences, owned spice lands and farm lands located closer to the Kolonna town and some other historical tourist attractions. The majority of farmers in Kolonna were pepper and cinnamon growers while few were growing tea and banana in combination with pepper or cinnamon. These mono-cropping as well as multi cropping situations would provide attractive models in spice-tourism. Hence, though there is no spice-tourism conducted by even a single farmer yet in the Kolonna DS division, the majority of spice growers are willing to start spice-tourism.

\section{Recommendations}

Following recommendations can be made to farmers and government to initiate and develop spice-tourism in the Kolonna DS division. 


\section{Financial facilities for the farmers}

As the availability of finances is a serious problem, it is important to introduce a suitable loan or credit facility for the farmers to overcome this constraint. Government could intervene in this situation by introducing a subsidiary loan scheme for these farmers to initiate spice-tourism in the study region.

\section{Education and training for the farmers}

Although some farmers had the basic knowledge, skills and experiences on farming, and willingness to start spice tourism, they are poor in business management skills, entrepreneurship skills, management skills, interpersonal and communication skills, (especially English language). Therefore, education and training programmes for the farmers in these areas would be crucial for a successful implementation of the spicetourism program in the Kolonna DS division.

\section{Development of infrastructure facilities in the area}

Good infrastructure facilities are essential for the development of any tourism industry. Therefore, government should pay high attention on establishment of basic infrastructure facilities such as a good road network, transport facilities, electricity, telecommunication, safety and protection in the study area to attract visitors to the spice-tourism areas.

\section{Formulation of proper policies}

As development of tourism industry creates several social, cultural, environmental issues, there should be suitable policies to handle these issues effectively. Relevant government institutions should provide the policy and regulatory frameworks on these matters to support efficient and effective implementation of spice-tourism in the study area.

\section{Help in tourism marketing and promotional activities}

Although it is costly, development of tourism industry heavily depends on proper marketing and promotional activities. However, the spice-growing farmers in the study region are poor, without the ability to carry out an effective marketing and promotional campaign for spice-tourism on their own. Hence, the local government or other institutions should assist the farming community in this regard, to support the spice-tourism industry.

\section{References}

Barbieri, C. (2013): Assessing the Sustainability of Agritourism in the US: A Comparison Between Agritourism and Other Farm Entrepreneurial Ventures. J. Sustainable Tourism 21 (2): 252-270.

Colton, J.W. and Bissix, G. (2005): Developing Agritourism in Nova Scotia: Issues and Challenges. J. Sustainable Agriculture 27(1): 91-112. 
DEA (2014): Annual Report, Department of Export Agriculture, Peradeniya.

Das, B. and Rainey, D. (2010): Agritourism in the Arkansas Delta Byways: Assessing the Economic Impacts. Int. J. Tourism Res. 12(3): 265-280.

Mahaliyanaarachchi, R.P. (2014): Agro Tourism. Department of Agribusiness Management, Faculty of Agriculture Sciences, Sabaragamuwa University of Sri Lanka.

Malkanthi, S.H.P. and Routray, J.K. (2012): Visitor satisfaction in Agritourism and Its Implications for the Agritourism Farmers in Sri Lanka. Int. J. Agric. Management. 2(1): pp 17-30.

Mnguni, K.I. (2010): The Socio-economic Analysis of Agrotourism in Two Rural Communities in the Limpopo Province. University of South Africa, Department of Animal Health and Human Ecology.

Punyawardena, B.V.R. (2007): Agro-ecology (map and accompanying text), National Atlas of Sri Lanka, ${ }^{\text {nd }}$ Ed. Department of Survey, Colombo

Senanayake, S.M.P. and Wimalaratana, W. (2010): Agro-tourism and Rural Development in Sri Lanka: With Special Reference to Nuwara Eliya District. Research Report. Department of Economics, University of Colombo, Sri Lanka. 
Malkanthi et al. 